\title{
Letter from Grinnell: Emery S. Bartlett to His Children and Grandchildren
}

edited by Glenda Riley

In 1911, when Emery S. Bartlett was seventy-nine, several of his children and grandchildren requested that he write them a formal letter detailing his reminiscences regarding his life experiences and particulary relating to his move to pioneer Iowa. It is that portion of the letter that is presented here.

Bartlett was born on September 7, 1832 in Bath, New Hampshire where he was raised on a farm and educated in the New England Public School system. In 1852 he left Bath for a short stint at Olivet College in Michigan, then hired himself out as a farm laborer in Wisconsin. It was here in 1854 that he received a letter from his father describing a new settlement of Congregationalists in Poweshiek County, Iowa, later to be known as Grinnell. He had little difficulty in deciding to join his father, and journeyed westward to explore the Iowa settlement. He had even less difficulty in deciding to stay once he saw the area.

In late 1855, he left Grinnell to return to Bath to marry his fiance, Hannah S. Stevens, and to bring her back to their newlyconstructed home in Iowa. They shared a long and happy marriage which produced three children: Arthur, Stella, and Katherine. Both Hannah and Emery ended their lives in Grinnell: she on May 4, 1907 and he on May 3, 1915.

In the letter Bartlett mentions his sister Eliza Ann who migrated with the family to Iowa in 1855, married Benoni Howard of Grinnell in 1856, bore a daughter in 1859, and died in Grinnell in 1864. The letter appears with the generous con- 
sent and cooperation of Eliza Ann Bartlett Howard's grandson, Ralph L. Longley, now of Sarasota, Florida.*

. . FAther Sent me a NeWSPAPER Clipping, telling of a Christian Congregational Colony just starting at Sugar Grove, Poweshiek County, Iowa, and asking me to go out and investigate; but before I was ready to start he decided to come out himself. So about the middle of September he surprised me by appearing with a young man, John Lang, quite an intimate friend of mine, whom he had persuaded to accompany him. Right here let me say that Beaver Dam has always occupied a special niche in my memory, for it was while staying here that my dear wife and I agreed to sometime unite our destinies for life. Monday morning September 18 th we three hired a hack to take us to Madison, the first forty miles of our journey. Tuesday morning we took the stage for Galena, where we found the only railroad on the route, fifteen miles to Dubuque. Wednesday and Thursday took us to Marion, where we stayed over night, and Friday to Iowa City, fording the Cedar River at Cedar Rapids, as there were no bridges over either the Cedar or the Mississippi yet. Iowa City was a city in name only, tho it was the capital of Iowa with a very unpretentious stone building for Capitol, now used by the State University. Daylight Saturday morning saw us well started on the last lap of our journey. It was well known that the Western Stage Co. always used their best equipment on the eastern end of their lines, sending the poorer farther west where there was less travel, so as we were near the eastern end we had a very fair outfit, yet on one division on this last days ride it was said there were only three good eyes among the four horses; yet we arrived at Lattimers safely about nine o'clock in the evening, and slept on the floor in his log cabin with, I won't undertake to say, how many more.

We were out early Sunday morning, September 24th 1854, ready for our four-mile walk to the Colony where we could soon discern a few low shanties, on the otherwise naked prairie. We approached the largest building, a long, low structure some

*Irregularities in spelling, punctuation, and grammar have been retained. 
fourteen by sixty feet and seven feet high, with a curved roof, formed by bending green oak boards, and as I afterwards learned, affording very poor protection from rain, when umbrellas and even tables were at a premium. There was a little joke on Mr. Henry Laurence, who during a heavy shower one night, thought he had found a dry place under the table, but someone coveting the place, waited until he was sound asleep, then quietly moved him and appropriated the place himself. We were met at the door of this "Long Home" (as it soon came to be called) by Mr. and Mrs. Phelps who gave us a cordial welcome, and learning that we had had no breakfast, proceeded to get us the most appetizing meal I had enjoyed for a long time, tho it delayed meeting for an hour, as that was to be held in the same room. Mr. Grinnell preached, and a good share of the people attended.

Mrs. Grinnell had been here only a few days, with little Katie three years old, to whom I soon became very much attached. This September 24th 1854 was a perfect September day, and a notable landmark in my life for in all my travels I had never seen the place where I wanted to stay; but from the hour of my arrival here, I felt that this was home, and have never had any desire to change.

Father and John stayed until Wednesday, Father in the meantime buying 160 acres north of town, now owned by H. W. Spaulding, and 160

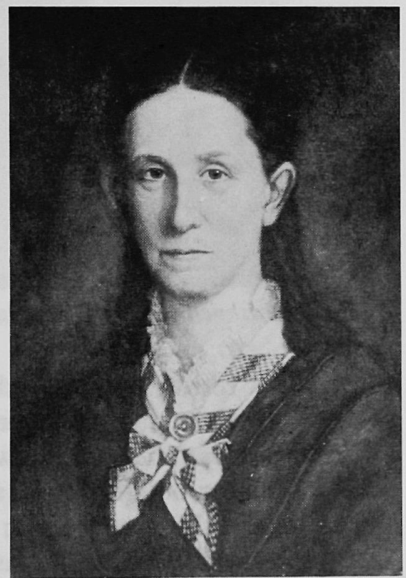

Julia Chapin Grinnell acres south of town, fifty-five of which I afterward bought and occupied, for all of which he paid $\$ 2.50$ per acre. Then as everyone must have a little timber, he bought in company with John Lang, the Lattimer place of 112 acres at $\$ 10$ per acre; but soon after returning home he bought John's interest, by paying his expenses for the trip. He also bought lots 3 and 4 in block 15 




Josiah Bushnell Grinnell, founder of Grinnell and Grinnell College.

where I now reside for $\$ 25$, with the stipulation that he build on one of them; and the two corner lots on south Broad street, where the Bliss tenements now stand, on the same terms.

I soon after bought lots 1 and 2 in block 15 , including the Edson lot, on the same terms; that is one lot free for building, and the other for $\$ 25$ as it was thought two lots were none too much for each house. I afterwards exchanged my two lots for Father's south ones, and when Mr. Hamilton thought he was going to get all the business at the south part of town offered me the two lots, opposite the Methodist church, where I afterwards built (in 1856) and $\$ 100$ in exchange, I let him have them; the more readily as there was already a good well dug on his lots.

The next day after I arrived I engaged board with $\mathrm{Mr}$. Phelps, sleeping first in one of the bunks at the east end of the 
"Long Home," and afterward in the upper story of Mr. Scott's store, with Henry Hill, Henry Laurence and Henry M. Hamilton until Mr. Phelps's house was finished about the middle of November, when I went there and remained with them until my folks came in May 1855.

I have always felt under obligations to Mr. and Mrs. Phelps for all they did for me while I was with them, for I have always felt that for some reason they favored me above all the other boarders. During this first winter Mr. and Mrs. Grinnell kept house in one room built on the south side of Mr. Phelps house, as their own house was not built until the next year. There has been quite a difference of opinion in late years, as to just where the "Long Home" was located; and as I lived in it for two months, and have lived just across the street the greater part of the time since, I think I am better qualified to locate it than any other person now living, and in fact there are very few persons yet living who ever saw it. Someone remarked that it looked much like a corn crib, and it was about as effective in keeping out rain and snow.

YOU WHO HAVE NEVER SEEN this country except as it is now, covered with cultivated fields and trees, almost like a timbered country, can scarcely imagine how it looked then, with not a tree or bush in sight except to the southwest, where the grove could be faintly seen three or four miles away, but in any other direction nothing as large as a hazel bush as far as the eye could reach. Until late in the fall there was not a shed, or fence, or even a hitching post on the prairie, all horses being tied to wagons, in many of which people were still living. About the first of November we had a cold spell, when it seemed as tho we should all freeze, as there was not a plastered house on the prairie, and very little wood and that perfectly green. Coal was not discovered in this section, if in the state, until some years later. We never burned any coal until 1864, and about the first we burned I hauled from Evans mines, twenty miles south, where such was the demand that, at one time I waited two days and two nights and then gave a man $\$ 1.50$ for his turn before I could get a load; but usually by starting at midnight, Monday morning, so as to get there by daylight, and running out my own cars, I could get a load so as to get home the same evening. It 
cost about three dollars per ton at the mine, and was rather poor coal. When the Iowa Central railroad was opened, I sold the first fifteen cars of coal brought here, and by delivering a part of it around town, cleared about sixty dollars.

Almost every evening that first fall we could see prairie fires in all directions. Sometimes it even looked like an almost continuous circle around us; but of course it was not continuous, as some fires were many miles away, while others were quite near. One evening it came up to where the Grinnell residence now stands and burned a stack of hay, and a pile of lumber which Mr. Grinnell had hauled from Muscatine for his new house. Deer were quite plentiful and we often had venison at $\mathrm{Mr}$. Phelps. I saw quite a herd one day about where Mr. Leisure's house now stands; and even the second winter, as I was hauling wood from the grove, there was a herd of seven near where I was loading every day for sometime. Wolves were often seen, and that first fall we were often wakened by their howling around the buildings at night, sounding as tho there might be scores of them while probably there were not more than three or four. Prairie chickens were not as plentiful as later, when there were more cultivated fields they became quite a pest doing great damage in the corn fields when the corn was left out late. While living on the farm I caught about eighty in traps, just across the road from the house, in two days. Rattlesnakes were very plenty, and I killed at least a dozen the first year, two of them under bundles of grain, as I raised them in binding; but I never let one escape, even getting off a load of hay as I was coming in after dark one evening, and guided by the rattle, succeeded in killing him with my fork.

Until the summer of 1855 we were obliged to go to Westfield for all our mail, and there was great rejoicing when the first stage coach came through, after we had marked a trail by plowing a furrow on each side for several miles; tho they came this way only every other day for some time. By the way I noticed in last evening's paper an account of the death of one of those old time stage drivers, a well-known character, Old Jake. I remember at one time, when he was instructed to get a certain friend of the officials of the company through on time, he killed two horses between here and Newton. 


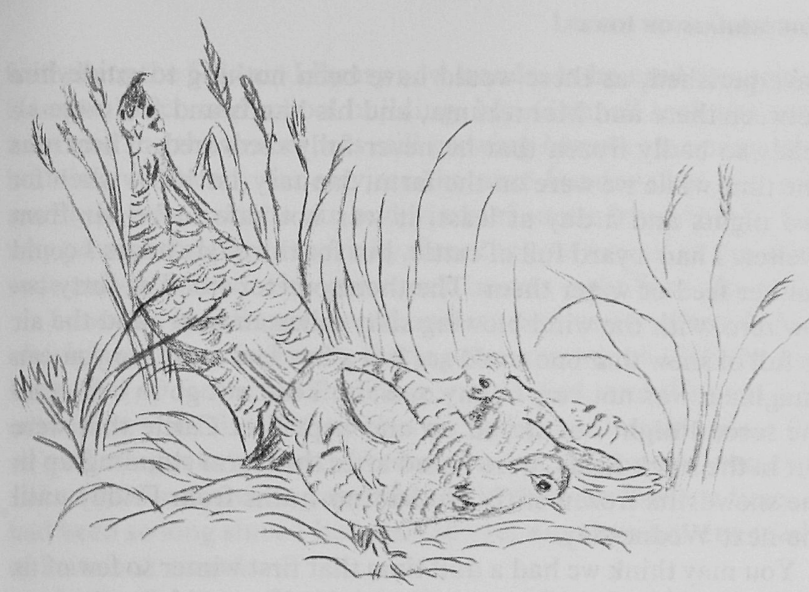

Prairie Chickens

It was several years before we had any sidewalks and sometimes when walking became almost impossible, we would haul in straw and spread it on the most frequented paths, which would help for a few days.

We felt quite cityfied when we were able after some years, to put down, on some of the main streets, two parallel lines of plank with a space of one foot between which was a great improvement especially if one had practiced tight rope walking, but was not an ideal lovers walk. The hope was to sometime fill in that vacant space, but that hope was never realized.

Can you realize that there was not a mile of railroad in the state when I came here, and the only wagon road near here was the old state road, used by the stage company, three miles south. The trails over the prairie in the fall of ' 54 were very faint, and hard to follow after dark, so when anyone was late getting in it was customary to ring the bell or run up a lantern on the flagpole, like a small light house on the ocean. It was especially dangerous being out after dark in the winter when blizzards were so frequent and landmarks so few. One man with horse and cutter started for Marshalltown, and being overtaken by a blizzard, wandered around nearly all night, but finally struck a fence at the extreme northeast corner of town and reached Capt. Clarks, when if he had gone a few rods farther east he must certainly 
have perished, as there would have been nothing to guide him between there and Montezuma, and his hands and feet were already so badly frozen that he never fully recovered. There was one time while we were on the farm, January 1st 1864, when for two nights and a day at least, it was not safe to be far from shelter. I had a yard full of cattle, but for thirty-six hours I could neither feed or water them. The thermometer stood at forty below zero, with the wind blowing sixty miles an hour, and the air so full of snow that one could see but a few feet away, so you can imagine it was not very balmy outside. I did not go to bed at all the second night but stayed up and kept fire. Cattle that were out in the stock fields, were found after the storm standing up in the snowdrifts frozen stiff. We had no trains from Friday until the next Wednesday.

You may think we had a dull time that first winter so few of us and so little communication with the outside world; on the contrary we thoroughly enjoyed it; we were like one big family, everyone interested in every other one, and all looking ahead for better things to come. If one was away, we knew where he was and when he would be back; and if a stranger came, we sighted him miles away, and soon knew who he was, what he was here for, and how long he was going to stay. We did not have a great variety of entertainment but always had morning and evening services on Sunday, very generally attended, prayer meeting on Thursday evenings, choir rehearsals each week led by Gideon Gardner, and an occasional social gathering. Meetings were held in the Long Home until cold weather, when we rented the north half of the upper story of the Grout Hotel, just finished, on the corner where the Colonial Theater now stands. Very early in 1855 , ten of us contributed fifteen dollars each for the erection of a building 16 by 24

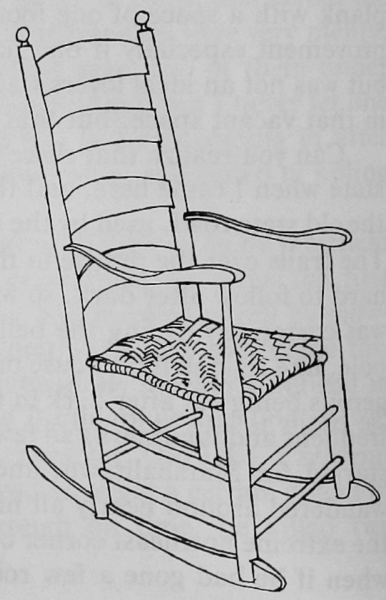
426 
feet where the Stewart Library now stands, to be used temporarily as a church and school building. Mr. Grinnell took the contract and tho the timber was still growing Monday morning, the building was ready for services the next Sunday; but you will readily believe that the sun and winds of summer made it by fall very poor protection, especially since the roof as well as the sides were only battened with green oak boards right from the mill.

Later the building was sold and we each received ten dollars of original fifteen invested. During the summer of 1855 the two story $40 \times 40$ foot school building was erected, and the west side of the first story finished, so that we had a comfortable place for all gatherings that winter. I remember yet the strange sensation as I walked into meeting over that solid floor for the first time; it had been so long since I had walked over any floor but one made of loose oak boards.

As the Congregational Association of Iowa had been invited to meet here in June of 1856 and we needed a larger room, we got busy and at six o'clock one evening had just finished driving the last nail in the floor and lath, and had the rubbish swept out ready for the first meeting that same evening. The next morning several young people, your Mother and I among them, went to the grove for loads of bushes and flowers for decorating, the new lathing making ideal ground-work, so that we had a very attractive room. As the cars came only to Iowa City, lumber wagons were sent to bring all delegates and visitors here, and return them after the meetings were over, free of all expense.

I doubt whether any meeting of the association has ever been enjoyed more, even tho some of the guests were obliged to sleep on the floor; I think however it was usually the hosts who occupied the floor; I remember our floors were well covered, but I am sure our guests, which were many, all had beds.

But I am getting ahead of my story and will go back.

In January 1855 as carpenters were scarce here, Father sent out B. G. Howard to assist me in putting up buildings, and Mr. Sutherland came with him. I had part of the timber for framing already cut, and the rest was still standing in the grove. Monday morning Mr. Sutherland, Howard and I walked to the grove carrying our dinners, and while Mr. S. and I did the chopping, Howard did the hewing. We walked in at night, repeating the 
program until Saturday night, when we had everything that could be hewed, ready for the house, barn and shed, and felt that we had done a good weeks work.

Then Mr. Phelps had the material on the ground for a barn, and I took the contract to put up and enclose that, which we did in January with no protection from the north wind, which came unobstructed straight from the north pole. But it was a very mild winter, I think the mildest I have ever known, and we really suffered very little; but the next winter made up for it, when we had several severe storms, so that one morning we carried out ten bushels of snow from the chamber where eight or ten of us were sleeping. The house progressed slowly as all finishing lumber including flooring, also hardware and glass, had to be hauled from Muscatine, which made everything expensive; so that there was some excuse for Mr. Scott, when a customer complained that five cents seemed rather high for a darning needle, pleading that freight was very high.

I think for the first year I was here, I averaged at least one trip every six weeks, either to Davenport, Muscatine or Iowa City; and there were not many houses between here and Iowa City where I did not stop at one time or another.

Every house was a hotel then and we were seldom turned away tho we sometimes wished we had been. Sometimes we were caught in the mud. I remember once I was obliged to leave a part of my load six miles beyond Iowa City, and more beyond Marengo. Once a wagon wheel went down under a heavy load of lumber near Homestead, detaining me two days. I occasionally had company, but usually went alone; the trip to Muscatine taking about eight days, one day being consumed in buying my load, and executing my various commissions which included almost everything, from lumber and hardware to dress goods and millinery. I remember when Eliza Ann was to be married, I was commissioned to select her wedding bonnet, as well as some furniture and various other things. On this trip I had a bureau for Eliza Ann and one for Hannah (the large plain one now in one of the chambers), the only two I could find in Iowa City, on top of my heavy load, yet I drove about forty miles the last day in the midst of a January snow storm, walking nearly all the way beside my team, to reach home that evening. 


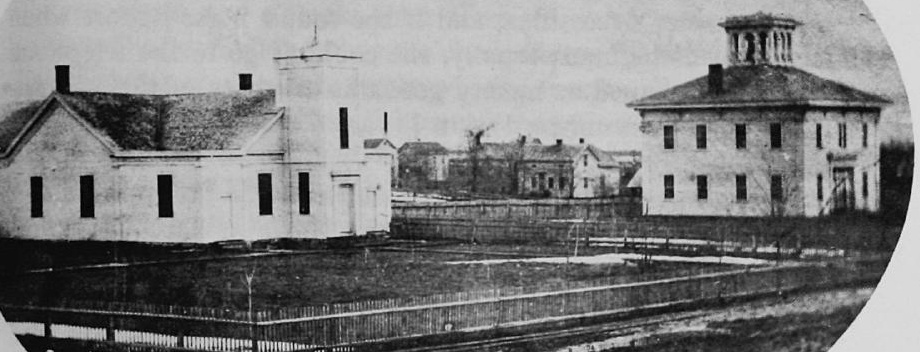

Congl Chureh is60-1899-6rinnoll lown

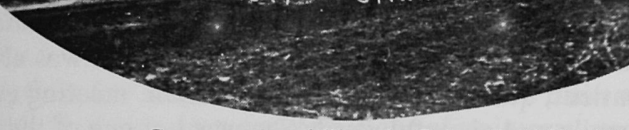

Congregational Church, Grinnell, 1860-1879

When Father wrote me that they would start west Monday morning, May 1st. 1855, I prepared to meet them in Muscatine Saturday night. I can never forget my sensations as I stood on the wharf just at dusk and saw the boat coming down the river; and the thought came over me that all of our family (except Moses who was in Dartmouth) was on that little boat; and the only home we had was the little unfinished house on the prairie one hundred and twenty-five miles away; and the tears came in spite of my efforts to control them. But my sorrow was soon turned to joy at meeting them all, safe and well, after their long, hard journey. ...

We had a very enjoyable day at the hotel over Sunday; and after making some necessary purchases Monday morning, were ready to start west. Father engaged a hack to take the family through, except Stanley who was to ride with me on the load of trunks, building material, and other suplies.

The house was far from finished; but a rough floor was laid in the upper story, and we took possession, partitioning off rooms with quilts and blankets; and making bed-steads by nailing poles to the studding, and there we lived through the summer. It has always been a mystery to me how Mother endured that long hot summer, with all the family she had to pro- 
vide for, in that one room used as kitchen, dining room, sitting room and sleeping room, and destitute of almost everything we now consider necessities; and if she found herself short when company came unexpectedly, she couldn't go to the telephone and order canned or bakery goods as all three of these necessities were then unheard of in Iowa.

There WERE SEVEN in our own family, beside the workmen on the house, and Mr. Sutherland, and Uncle Willard Child and Ellihu Hibbard came very soon and remained through the summer while they built their mill at Rock Creek. Besides several boarders, there were numerous visitors who stayed for days or weeks, but no one ever heard her complain. Tho Mother was always more or less of a sufferer from some spinal trouble, and for years, a little earlier, almost confined to her bed, she was always the same patient, quiet, happy, even-disposition, meeting everyone with a smile and cheerful word. She was not one of the bustling kind, but one of the best all-around housekeepers I ever knew, and one of whom it could truly be said, "She looketh well to the ways of her household, and her children rise up and call her blessed." New families were continually coming, and when they had nowhere else to stay, there was always room at our house for one more.

About the middle of November I decided to go for Hannah and as I wanted to start as early in the week as possible, and the stage went through here only every other day, it was necessary to go to Lattimers Monday evening, and take the line by way of Montezuma, Iowa City, and Muscatine, then to Rock Island by boat. This brought me into Chicago at midnight, Wednesday, and incredible as it may seem now, I was obliged to find my way alone on foot through entirely unlighted streets, for a mile, from one depot to the other, and I do not think I saw a person in the whole distance.

I reached White River, Vt. at 3 p.m. Saturday and there the train came to a full stop, not to start again until Monday at the same hour. Just think of it; within forty miles of my destination, and not even a freight train for two whole days. That road certainly observed the Sabbath and I am glad to be able to say that I attended church, even tho I had to cross the river into New Hampshire to do it. 
I remained in Bath about three weeks, and in the meantime Thanksgiving came; we had of course a big dinner at Mr. Sanborns about one o'clock; then Hannah and I were invited to Uncle Dudley Childs for a six o'clock dinner for which they had made great preparation, but to which I fear we were hardly prepared to do justice. Then Friday noon another big feast at John Walkers, which they had been saving for us, with another at Uncle Richard Childs at six o'clock. After this we certainly felt that we had all the Thanksgiving dinners we wanted for some time.

We were married by Rev. Thomas Boutelle, pastor of the Congregational Church in Bath, at eight o'clock Tuesday morning, December 11 th 1855 with only the Sanborn family and Michael, Sarah, Rhoda, and Maria Stevens present, and at nine o'clock were on the train at Bath Village, ready for our journey. The first day took us to Rutland where the train stopped over night; then two days and one night of uninterrupted travel took us to Marshall, [Michigan], where I found a hack to take us to Olivet the same evening. We remained in Olivet until Monday when we came to Chicago, and Tuesday to Davenport. You will remember that dining and sleeping cars were not yet invented, so that trains usually stopped over night at all important points; and tickets bought and baggage checked at frequent intervals. While waiting in Davenport, we went to the jewelers and bought the set of teaspoons, which have been in constant use ever since.

The railroad was just completed to Wilton Junction, Iowa, so we came there on the cars, and from there to within six miles of Iowa City on a construction train of flat cars, and from there to Iowa City in the stage. Thursday was a lovely, warm day and we enjoyed the stage ride over the prairie. I well remember how enthusiastic Hannah became over the sunset view of the bluffs between Marengo and Brooklyn, tho there was no Brooklyn then, or for several years after.

As we alighted from the stage at midnight, the wind was just beginning to blow from the northwest, and from that time on we had very severe cold weather for several weeks.

During the summer of 1856 I worked with J. M. Ladd, a carpenter, and at the same time built my own house 20 by $24 \mathrm{ft}$. on the corner of Park St. and Fifth Avenue. Child and Hibbard 
furnished the most of the lumber, and being friends of mine, they selected the best for me, especially the black walnut siding and inside finishing, which would probably be worth more now than the whole house cost me. I never painted the siding but kept it oiled, and that with the white trimmings made a very pretty house. While as well built as the majority of houses then, we should hardly call it a well built house now; for the walnut siding nailed directly to the studding soon warped, so that one could almost run their fingers between the boards, and with one thin coat of plastering made very poor protection from the winters cold. The winter of '56-'57 Prof. Parker rented the front room and the only finished chamber, for his family of five; while we had the kitchen and bedroom and a very small pantry; and had one boarder who occupied a home-made folding couch in the kitchen. In the spring of ' 57 Ellihu Hibbard was married, and brought his bride directly to our house.

We boarded them for a year or more and here their only son Clarence was born. Alice Howard also was born here, April 22nd. 1859, and last but not least, you Arthur were born here at two a.m. May 21st. 1862 . In the spring of 1863 I sold this house and two lots for seven hundred and fifteen dollars, which would seem now almost like giving it away, but a very fair price then. Then, Arthur, while your Mother took you east for a four months visit, I built the house on the farm, living meanwhile in one half of Fathers house on fifth avenue. Our first election was held April 1st. 1855, when there were twenty voters, of whom only one Samuel Harris now of Colorado, besides myself, is now living; but at the presidential election in November of the same year there were one hundred and twenty votes cast, of which one hundred and five were for Fremont, and four for Buchanan. My vote of course was for the Pathfinder, and has ever since been for the republican candidate. Our town elections here are very differently conducted from those in New Hampshire.

There it required a majority of all votes cast to elect, so that it sometimes required several ballots for each office and as only one office was considered at a time, it was an all day job often extending into the second day. Town meeting, as it was called, was always held in the old meeting house, when it was always crowded, and it was far from a religious assembly. There were 
two brothers, Horace and French, who for years never failed to be there with several trunks full of molasses candy, which was a great treat to those of us boys who could raise a few pennies.

In 1856 in spite of my vigorous protest, I was elected constable, and my first job was driving to Malcom about midnight, to arrest a stage driver accused of stealing, but that was easy as I caught him asleep in bed. Then Amos Bixby was having trouble with the stage drivers about tearing down his fences and driving across his field to avoid a mud-hole, and he called upon me to go and lie under the fence the greater part of one night to arrest the driver; but it so happened that they did not come through that night. But a day or two later he had Capt. Clark there with a rifle, and when they started through, Clark shot one of the lead horses killing him instantly. The stage company immediately sued Bixby for damages, but after quite a lengthy trial, in which Bixby was his own lawyer, he was acquitted. While I was attending this trial, a man named Thomas, alias Cumquick, was brought up accused of the murder of a man and his wife whose remains were found hidden in corn shocks, just west of Montezuma. It was a very aggravated case, and no doubt of his guilt; and when he applied for and was granted a continuance, the people were aroused and a crowd gathered in the evening declaring he should not leave town alive. But when Judge, afterward Governor, [W. M.] Stone came out and made a little speech assuring them he should certainly be brought back and have a fair trial, it was decided to let him be taken back to the Davenport jail.

When however he was brought up again in June, and was granted a change of venue to Mahaska County, the crowd again gathered with the murdered woman's brother as leader, and he was quickly taken to the west end of Main St. where with a rope thrown over a convenient limb he soon expiated one of the most attrocious murders ever committed in this vicinity. It so happened that we, in company with the Hibbards, took a notion to drive to Montezuma that day, partly on business, and partly for pleasure; and arrived a few minutes after the job was done, but while he was still hanging from the tree. But the worst job I had as constable was when I arrested a man accused of horse 
stealing; for, as we had no place of confinement here, or even in the county, I was obliged to guard him for about a week, until it was decided what to do with him. Then Oskaloosa being the nearest jail, I was ordered to take him there. So with a driver from the livery stable, I took him there only to find that they had disposed of their jail, and were no better off than we; so the only thing to be done was to guard him one night there and bring him back by way of Montezuma and guard him another night at home. The next morning I took another start by stage for Iowa City, expecting to reach there the same night; but the roads were bad and night overtook us at Marengo. By this time I was getting tired, but I had the landlord lock us in a room and sleeping with one eye open I managed to get through another night and the next afternoon reached Iowa City. There they told me their jail was not safe and advised me to go on to Davenport; but I had had enough of his company and didn't care much if he did escape after he was off my hands, so I told them he was good and I guessed wouldn't try to break out, and left him. I think by that time, the prisoner had become quite attached to me; for he shed tears when I bid him goodbye, and begged me to come and see him again before I left town. There was some compensation for all this trouble, for while the pay was by no means large, I think it was more money than I received from any other source for the year.

I hope none of you may ever be quite as short of money as we were in 1857 and '58, I was trying to farm, and all the produce of all kinds, which I sold for cash in one year amounted to less than ten dollars. Corn and oats were worth about ten cents per bushel in trade, but no money to buy, and no means of shipment. I remember a girl, who was boarding with us, brought from home a ten dollar bill and wanting to apply a part of it on her board, I went all around town to find someone who could change it; and all wondered where so much money could have come from. Sometimes we could scarcely raise money to pay postage on a letter, and there were weeks when we had no sugar in the house, only sorghum molasses of our own raising. We really suffered during the winter for want of clothing to keep us warm.

Even as late as 1863 I sold dressed pork for $\$ 2.35$ cents per 
hundred. Taxes were not paid for four or five years, but property was not sold as there was no one with money to buy. I think I never saw Father more surprised than when he was one day refused credit at the store for the first time in his life; but the merchants were as badly off as any of us.

I ought to have mentioned in its proper place how greatly surprised I was one December day in 1854 at the appearance here of cousin George Child. I had not supposed I had a relative in the state; but it seems he had just located at Nevada, and learning in some way that I was here, had immediately hitched to his lumber wagon, and come the two days drive to call upon me. We were great friends when we were boys, living within one fourth mile of each other, and we had a fine visit in the two days he was here; he drove home in two days more. I afterward drove from Nevada in one day (tho not in a lumber wagon) even then missing the way so that at noon we were only fifteen miles from Nevada. There were few roads and less fences, so we drove straight across the prairie, heading for some point miles ahead, never stopping for sloughs unless there was a ditch, and there were few ditches until the sod was broken.

Uncle David Child's family, very soon, all removed to Nevada, except Mrs. Laurence, (Charity) who remained in Peoria, so that we often had a visit from them, as they drove back and forth; and a whole wagon load of the young people drove down at one time to make us a visit. I remember too that Aunt Charlotte and Leroy drove down in the winter of 1857-8 for a few days visit, and on account of storms and drifts had to remain for three weeks, and then were nearly a week in reaching home. That was the winter when we had four feet of snow, and the only way to get to the grove for wood, was to follow the stage road; and if two teams met, the lighter must be forced off the track while the other passed, and then all hands help get them up on the road again.

I think with Mr. Grinnell I can claim the honor of setting out the first trees on the prairie. Very early in the spring of 1855 before even a bush was started, as I had a horse and wagon, Mr. Grinnell proposed that he and I go to the grove for a load of small trees, of which he set a part on the lots where he was about to build, and I put the rest in front of where I now live. The most 
of these lived for a year or two and then died a natural death as the prairie was not then a congenial home for timber trees. Then in 1856 Stanley and I went to Montezuma with a hayrack, and got a big load of locust trees from a grove there, which did well for a few years, until the borers attacked and ruined them. Then we went into the old cultivated fields around the groves and dug the volunteer cottonwoods, and a few of these may be with us yet. Finally, the most successful thing I did was to go to Skunk River, and gather maple seeds, which I planted around the farm house, and in the field, and from which I afterward sold large numbers. I think all the maples in the cemetery came from my grove. I also planted, I think in 1865 , some black walnuts which are now growing beside the road at the farm. The big apple tree on the alley is from seed which I brought from Grandfather Child's orchard in Bath in 1855, and planted by Father in the spring of 56 .

I want to put on record too that the large oak gate post now standing just west of my barn, was put there in 1855 and is still apparently sound, except for decay at the top, after fifty-seven years of service.

When the war of the rebellion broke out, I never quite felt that it was my duty to enlist, and when our quota for the township was assigned us with the privilege of paying a certain amount towards hiring substitutes, I, with others, paid the assessment (about $\$ 100.00$ each if I remember rightly) and thus avoided a draft.

We also organized a company of militia; of which I was made sergeant, which drilled regularly, and were always ready for service in the state. Washington and Sugar Creek townships did not supply their quota of men as that was the strong-hold of southern sympathizers. On the contrary they organized a company of "Knights of the Golden Circle" as they called themselves, and drilled in secret regularly, for the purpose of resisting the draft and aiding the rebellion; and even made threats of coming up and burning this town, as the U.S. Marshall's office was here from which the draft was made, so that for several nights we were on guard at all approaches to the town. But things came to a climax when two U.S. Marshalls were sent in to arrest drafted men who failed to report, and were consequently treated as deserters. 


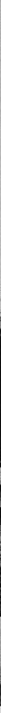

Foster and Bailey Implement Store in Grinnell, circa 1907

The copperheads were drilling in the woods at the time and learning of the presence of the officers in the vicinity, sent the two Fleener brothers to waylay them, which they did, killing one instantly, the other living long enough to give an account of the whole affair. The murderers immediately fled to Missouri, probably joining the rebel army, and have never been heard from since. The man named Gleason, who reported the presence of the marshals to the company and guided the Fleeners to them, was shot in the leg by the marshal, sent to the penitentiary and died there soon after.

The Governor immediately came down and armed our company with new Springfield rifles, in place of the older guns we had been using, with plenty of ammunition, and ordered a mounted squad of us to go down and arrest the whole copperhead company, a list of which had in some way been secured. We were also to make a thorough search for arms and ammuni- 
tion, of which we found at least one gun and one revolver at each place, with any amount of ammunition hidden away in all conceivable places.

We confiscated a team to bring in the men as fast as we got a load, and the guns we put in the wagon, but the revolvers we put in our own pockets until we each had one, thinking they might come in play before we were through, as we were warned that some of them had threatened to shoot the first man who attempted to arrest them. But the most of them were badly frightened, and none of them made any resistance. The captain, Rob Carpenter, was nearly the first captured, and I have often smiled as I thought of the figure he cut when he found himself seated in the wagon. It was a cold rainy afternoon in October; but he had on a long, heavy overcoat, and might have made himself tolerably comfortable, but instead he elevated his feet onto the dashboard, and unbuttoned and threw back his coat, exposing the full length of his long legs to the drenching rain. We were down there three days, and gathered in about sixty prisoners whom we guarded in a warehouse here in town for about a week, and then released without any further action being taken against them, so far as I recollect. I remember I drew pay for thirteen days service. Some of these men were our neighbors; the Jenkins, Prossers, Beelers, Pierces, etc. nearby, while others were some of them twenty miles away. The next year Captain Carpenter sued four of us, Prof. Parker, F. H. Bixby, Mr. Bruce and myself for ten thousand dollars personal damages, and we were obliged to go to Toledo to defend the case in court.

One of the ablest criminal lawyers in the state volunteered to defend us free of all charge; and after quite a sensational trial we were victorious and came home with flying colors. I suppose if they had won that case, they would have brought about fiftynine others. Capt. Carpenter afterward charged me with keeping his revolver to which I could truly plead not guilty, and we later became quite good friends.

Being the only one living on the road to town, who was at all active in the affair, there were some fears that they might vent their spite on me; but aside from an occasional hallow as they went home late at night, and once an onion thrown through the window after we were all in bed and asleep, probably by some 
drunken fellow, we were not disturbed. In 1873 having decided to quit farming, I bought a half interest in the meat market with Henry Hill and we continued in business together for nearly three years. There were four markets at that time, and competition being so strong, and with so little trade it became impossible to support two families on the profits; and the whole financial responsibility being on my shoulders, I felt that a change must be made, and on my making a definite proposition to either buy or sell, Hill turned the whole over to me. Then began a life and death struggle for existence, when for two or three years, with my utmost exertion and strictest economy, I could scarcely tell whether I was gaining or losing and had it not been for the little money my dear wife saved by taking a few boarders, I must certainly have gone under. Then as one after another of my competitors dropped out, things began to look brighter. An occasional new firm would start in, run for a short time, and then disappear; and I think I had from twelve to fifteen different competitors while I was in business; and at one time I had the satisfaction of having the only market in town, and was doing a very fair business. For the first two or three years we could only dispose of one beef in two days, and during the hot weather as we had no cooler of any account, we would exchange with one of the other markets, each killing on alternate days and dividing the meat. We usually bought only one or at the most two beeves at a time, and often did not know at noon where the one was coming from to kill that night. Then as business improved, I put in a good cooler in the market, and a large one with capacity for thirty beeves at the slaughter house, and was prepared to keep a supply of meat on hand. I also had plenty of pasture so that I was prepared to handle all kinds of stock and often made more in that way than I was making in the market. I claimed to have the best cattle horse as I surely had the best dog in this vicinity, so that I really enjoyed going out and buying and driving in a herd myself, which I flattered myself I could do a little better than anyone else. I really enjoyed this work, and had I been ten years younger, would not have given it up, but when I was sixty years old, I began to feel that the life was a little too strenuous, and that I had better begin to take things a little easier.

What little financial success I have had I attribute not to 
any particular business ability or shrewdness, but to my stick-toit-iveness which has often stood me in good stead.

My most successful financial venture was when I bought the Jessup place, on not over ten minutes notice, paying only two hundred and ten dollars down and running in debt for twentyfive hundred. This was about $\$ 13.50$ per acre and I afterward bought the Simmons eighty for about $\$ 16.00$ an acre, and sold the whole for $\$ 50.00$ an acre, after the railroad had paid me about five hundred dollars more than the whole had cost me.

In 1875 Father and Mother decided they could no longer live alone, and asked us to come and live with, and care for them, which we did until their deaths, Father November 151879 , and Mother January 31st 1882 . They were never any trouble or care to us but always a comfort, as they both retained all their faculties to the last and were not long dependent upon anyone. I cannot recall that there was ever an unkind or unpleasant word spoken while they were with us, and it is one of my pleasantest memories that everything possible was done to make their last days happy, and we had the satisfaction of knowing that our efforts were appreciated.

While the writing [of this letter] has called up some sad memories, as well as pleasant ones, on the whole I have enjoyed it and only wish I had an abler pen with which to express my thoughts; but I am sure your love will overlook all faults and put the best possible construction on everything I have said.

If there has been any good in my life may it be remembered and profited by, and may my many mistakes and shortcomings be guarded against and overlooked.

Very affectionately yours, Emery Sargent Bartlett. 
Copyright of Annals of Iowa is the property of State of Iowa, by \& through the State Historical Society of Iowa and its content may not be copied or emailed to multiple sites or posted to a listserv without the copyright holder's express written permission. However, users may print, download, or email articles for individual use. 